\title{
American eel resilience to simulated fluid shear associated with passage through hydroelectric turbines
}

\author{
Brett D. Pflugrath*, Robert P. Mueller, Kristin Engbrecht and Alison H. Colotelo \\ Earth Systems Science Division, Pacific Northwest National Laboratory, 902 Battelle Blvd, Richland, WA 99352, USA
}

Received: 8 December 2020 / Accepted: 14 April 2021

\begin{abstract}
American eel (Anguilla rostrata) populations have declined within their native range along the eastern coast of North America due to factors such as commercial fishing, habitat alteration, and dams. American eel are catadromous fish species, and high mortality rates $(>40 \%)$ have been observed for freshwater life-stage adult eel passing downstream through hydropower turbines. Lacerations and sectioning of fish have been observed downstream of turbines and these injuries are commonly associated with direct contact with the turbine runner, whether through blade strike or pinching and grinding. Exposure to fluid shear may also be a source of injury, however, little is known about American eel susceptibility to this physical stressor. Eels are considerably flexible when compared to other fish species and lack other morphological characteristics that would make them susceptible to fluid shear, such as protruding eyes, large scales, and large operculum. European eel, which have previously been tested for susceptibility to fluid shear, were found to be resilient. To determine if American eel are also resilient to fluid shear, forty American eel were exposed to a water jet, simulating severe fluid shear (strain rate $>800 \mathrm{~s}^{-1}$ ) that fish may experience when passing downstream through turbines. No immediate or delayed $(48 \mathrm{~h})$ signs of injury were observed after exposure to severe fluid shear. Based on this study, and a previous study conducted on American eel susceptibility to barotrauma, the source of injury and mortality of American eel passing through turbines is likely attributed to blade strike or pinching and grinding.
\end{abstract}

Keywords: Fish passage / hydropower / water jet / stressor / morphology

Résumé - Résilience de l'anguille américaine au cisaillement simulé du fluide associé au passage dans les turbines hydroélectriques. Les populations d'anguilles d'Amérique (Anguilla rostrata) ont diminué dans leur aire de répartition d'origine le long de la côte est de l'Amérique du Nord en raison de facteurs tels que la pêche commerciale, la modification de l'habitat et les barrages. L'anguille d'Amérique est une espèce de poisson catadrome, et des taux de mortalité élevés $(>40 \%)$ ont été observés chez les anguilles adultes au stade de la vie en eau douce qui passent en aval des turbines hydroélectriques. Des lacérations et des sections de poissons ont été observées en aval des turbines et ces blessures sont généralement associées à un contact direct avec la roue de la turbine, que ce soit par le choc des pales ou par le pincement et le broyage. L'exposition au cisaillement du fluide peut également être une source de blessures, mais on sait peu de choses sur la sensibilité de l'anguille d'Amérique à ce facteur de stress physique. Les anguilles sont considérablement flexibles par rapport aux autres espèces de poissons et ne possèdent pas d'autres caractéristiques morphologiques qui les rendraient sensibles au cisaillement des fluides, comme des yeux saillants, de grandes écailles et un grand opercule. Les anguilles européennes, dont la sensibilité au cisaillement des fluides a déjà été testée, se sont révélées résistantes. Pour déterminer si les anguilles américaines sont également résistantes au cisaillement des fluides, quarante anguilles américaines ont été exposées à un jet d'eau, simulant un cisaillement sévère des fluides (taux de déformation $>800 \mathrm{~s}^{-1}$ ) que les poissons peuvent subir en passant en aval des turbines. Aucun signe de blessure immédiate ou différée (48 heures) n'a été observé après l'exposition à un cisaillement important du fluide. Sur la base de cette étude, et d'une étude précédente menée sur la sensibilité de l'anguille d'Amérique au barotraumatisme, la source de blessure et de mortalité de l'anguille d'Amérique passant à travers les turbines est probablement attribuée au choc ou au pincement et au broyage des pales.

Mots clés : Passage des poissons / hydroélectricité / jet d'eau / facteur de stress / morphologie

\footnotetext{
*Corresponding author: brett.pflugrath@pnnl.gov
} 


\section{Introduction}

Many freshwater eel populations around the word have declined, including American Eel (Anguilla rostrata; Dekker, 2003). American eel support a viable fisheries and are a culturally significant food source to many Native American tribes of the US and First Nations peoples of Canada (MacGregor et al., 2008). The Committee on the Status of Endangered Wildlife in Canada listed American eel as a threatened species and American eel were listed as an endangered species under Ontario's (Canada) Endangered Species Act in 2008 (Tremblay, 2012). Additionally, American eel are listed as endangered on the Red List of Threatened Species by the International Union of Conservation of Nature (IUCN) and the populations trend is currently assessed by the IUCN as decreasing (Jacoby et al., 2017). Several factors are have led to the decline of American eel populations, including commercial fishing, habitat alteration, and dams (Jacoby et al., 2017). Dams cause migrationalbarriers and can directly expose fish to stressors, particularly when fish pass downstream through hydropower turbines (Čada, 1997).

When passing downstream through hydropower turbines, fish can be exposed to several stressors, including blade strike, pinching or grinding within moving parts of the structure, rapid decompression, and fluid shear (Čada, 1997; Neitzel et al., 2004; Brown et al., 2012b; Bevelhimer et al., 2019). Mortality rates vary greatly between different turbines, but rates greater that $40 \%$ have been observed for American eel passing through turbines (Eyler et al., 2016). American eel susceptibility to blade strike has been observed in laboratory testing, where mortality occurred in $35 \%$ of American eel when exposed to simulated turbine blade strike over various combinations of blade thicknesses, blade velocities, strike locations, and fish orientations (Saylor et al., 2019). Studies have linked turbine induced injuries and mortality in American eel to strike or pinching and grinding because the observed injuries included lacerations or complete sectioning of the fish (Heisey et al., 2019; Saylor et al., 2019). However, there is potential that injuries can also be caused by exposure to rapid decompression (e.g. swim bladder rupture, internal hemorrhaging, and gas emboli) or fluid shear (e.g. spinal fracture), which can result in injures that may not be visually observed during an external examination.

Though rapid decompression has been observed to be a potentially significant source of injury or mortality for several fish species (Brown et al., 2012a; Pflugrath et al., 2018, 2020), American eel have a very low susceptibility (Pflugrath et al., 2019). This is primarily because American eel are a demersal fish and don't fill their swim bladder to achieve neutral buoyancy like pelagic fish (Pflugrath et al., 2019). The expansion of the swim bladder, which responds according to Boyle's law during decompression, is the major driving force of barotrauma in fish (Brown et al., 2012b; Pflugrath et al., 2012). Additionally, American eel have a physostomous swim bladder, possessing a duct connecting the swim bladder to the gastrointestinal tract that allows them to quickly inflate or deflate the swim bladder. And, American eel are particularly adept at quickly evacuating gas from the swim bladder when decompressed (Pflugrath et al., 2019). These traits, reduce the capacity of the swim bladder to expand and overinflate during decompression, consequently reducing the likelihood that American eel will suffer swim bladder rupture and barotrauma (Brown et al., 2012b; Pflugrath et al., 2012).

Though the susceptibility of American eel to fluid shear has not been examined, it has been examined in European eel (A. anguilla) which were found to be very resilient (Turnpenny et al., 1992). No injuries were observed when fish were exposed to a submerged water jet with a jet velocity of $20.7 \mathrm{~m} \mathrm{~s}^{-1}$ creating an exposure strain rate of $1153 \mathrm{~s}^{-1}$ (Turnpenny et al., 1992; Neitzel et al., 2000). European eel are very similar to American eel, with minimal genetic variation between the two species, only differing slightly on genes that contribute to growth and metabolism (Jacobsen et al., 2014a, 2014b). These slight genetic differences result in the American eel maturing quicker than European eel. Because of the quicker maturation, American eel are larvae for a shorter period and leave the Gulf Stream in search of fresh water sooner, which happens to place them near the Atlantic coast of North America (Pujolar et al., 2014). European eel remain in the Gulf Stream longer and exit near Europe (Pujolar et al., 2014). The two species have been observed to hybridize, and the offspring tend to mature at a rate between the two species and end up leaving the Gulf Stream near Iceland (Pujolar et al., 2014). Morphologically the two species are nearly indistinguishable except that European eel have more vertebrae, potential due to the longer maturation process (Avise et al., 1990). Therefore, due to their similarities, we hypothesize that American eel would have similar resilience to fluid shear as European eel.

To determine if American eel have a similar resistance to fluid shear as European eel, this study exposed American eel to a submerged water jet and assessed each fish for injuries and mortality. By determining the susceptibility of American eel to fluid shear, we can better understand the stressors that are causing injuries and mortality in eel passing through hydropower turbines, and implement measures, such as design and operational changes, to reduce these effects and help to restore native eel populations.

\section{Materials and methods}

\subsection{Fish acquisitions and handling}

Yellow-phase American eel were purchased from South Shore Trading Co. Ltd (Port Elgin, NB, Canada) and shipped to the Pacific Northwest National Laboratory (PNNL) Aquatic Research Laboratory (ARL) in September of 2019. Yellowphase eel may exhibit multiple life history patterns, including freshwater resident, saline resident, and interhabitat shifter. Because these fish were captured in fresh water, they are likely freshwater residents or interhabitat shifters and may encounter hydropower facilities while conducting both upstream and downstream migrations including the outmigration as they begin to convert to the silver-phase in preparation for spawning. Fish had a median length of $34.0 \mathrm{~cm}$ (range $=26.5-45.3 \mathrm{~cm}$ ) and weight of $53.0 \mathrm{~g}$ (range $=24.0-112.0 \mathrm{~g})$. Prior to testing, fish were held for 7 weeks in a circular tank $(2 \mathrm{~m}$ diameter and $1 \mathrm{~m}$ depth) with a water depth of $0.3 \mathrm{~m}$. Ambient filtered Columbia river water was continuously flowed through the tank, with temperatures slowly cooling from 17.6 to $12.4^{\circ} \mathrm{C}$ over the holding period. Testing was conducted at $12.6^{\circ} \mathrm{C}$. 


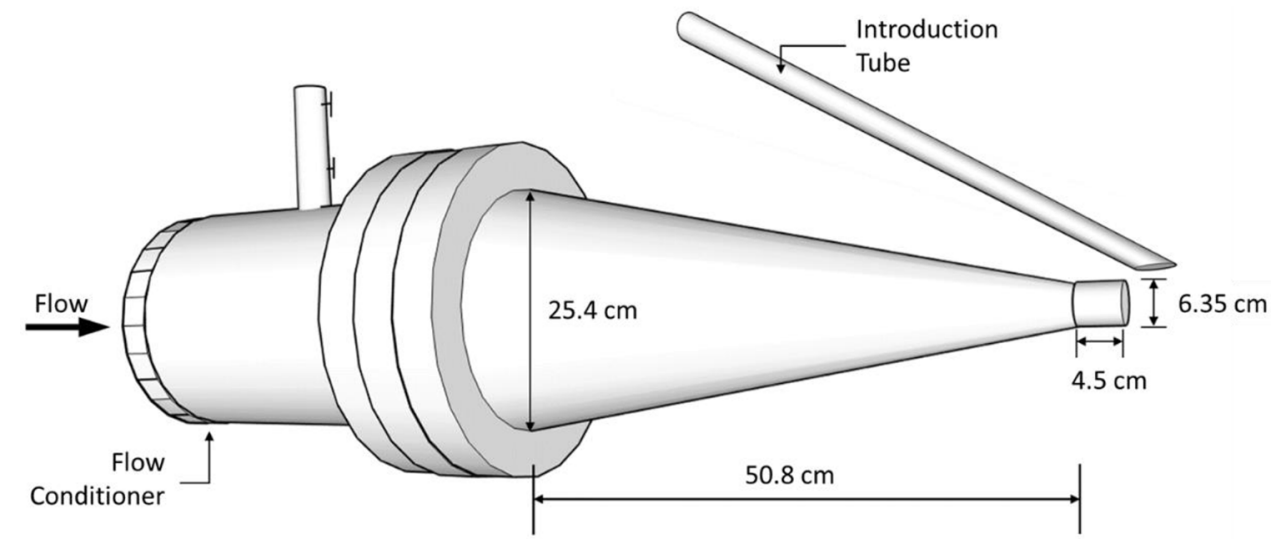

Fig. 1. Diagram of the Jet nozzle used to create an elevated fluid shear environment simulating fluid shear fish may encounter during turbine passage.

\subsection{Exposure to fluid shear}

All test fish were transferred to a shallow raceway to facilitate capture and transport to the test tank. Individual fish were collected from the holding tank and placed in a transparent acrylic tube with a diameter of $3.8 \mathrm{~cm}$ and a length of $60 \mathrm{~cm}$, hereafter referred to as the cartridge. The cartridge was paced in the trough and eel were allowed to volitionally swim into the cartridge, after which both ends of the cartridge were temporarily sealed - on one end with a rubber stopper, and the other end with a flexible polyurethane foam plug. Each fish was then visually examined within the cartridge for preexisting injuries or deformities.

Fish were then exposed to elevated levels of fluid shear, simulating values expected to be encountered during passage through a hydropower turbine (Neitzel et al., 2004), using a submerged water jet in a rectangular flume $(9 \mathrm{~m}$ long, $1.2 \mathrm{~m}$ wide, and $1.2 \mathrm{~m}$ deep), hereafter referred to as the shear flume (Neitzel et al., 2004). The jet nozzle (Fig. 1), which constricted flow from a $25.4 \mathrm{~cm}$ pipe to $6.35 \mathrm{~cm}$ over a span of $50.8 \mathrm{~cm}$ and had a $4.5 \mathrm{~cm}$ tip with a diameter of $6.35 \mathrm{~cm}$, was powered by an electronic-speed-controlled centrifugal pump with a capacity of $158 \mathrm{~L} \mathrm{~s}^{-1}$ (Neitzel et al., 2004). The pump was set to the desired speed and corresponding jet exit velocity. To introduce the fish to the fluid shear created by the jet, the foam plug was removed from the cartridge and the cartridge was placed on the end of an induction tube which was mounted to the top side of the nozzle at a $30^{\circ}$ angle from the direction of flow. Eel swam down the induction tube, headfirst and were exposed to fluid shear upon exit. This orientation of induction has been determined to be the worst-case scenario for fluid shear exposure (as opposed to tail-first) and is why this method was selected for testing (Neitzel et al., 2004). Fluid shear exposures were captured on two high-speed video cameras (PhotronFastcam Mini UX50, Photron USA, Inc., San Diego, CA, USA) to provide observation of exposure and identify the occurrence of any injuries. Cameras recorded at $1000 \mathrm{fps}$ and were positionedto record the nozzle exit through acrylic ports located on the side and bottom of the shear tank.

A total of 45 fish were exposed to fluid shear (Fig. 2) 20 at a jet velocity of $15 \mathrm{~m} \mathrm{~s}^{-1}$ (strain rate equivalent $=833 \mathrm{~s}^{-1}$ ), 20 at $18 \mathrm{~m} \mathrm{~s}^{-1}$ (strain rate equivalent $=1000 \mathrm{~s}^{-1}$ ) and 5 controls at $0 \mathrm{~m} \mathrm{~s}^{-1}$ (strain rate equivalent $=0 \mathrm{~s}^{-1}$ ). Strain rate was

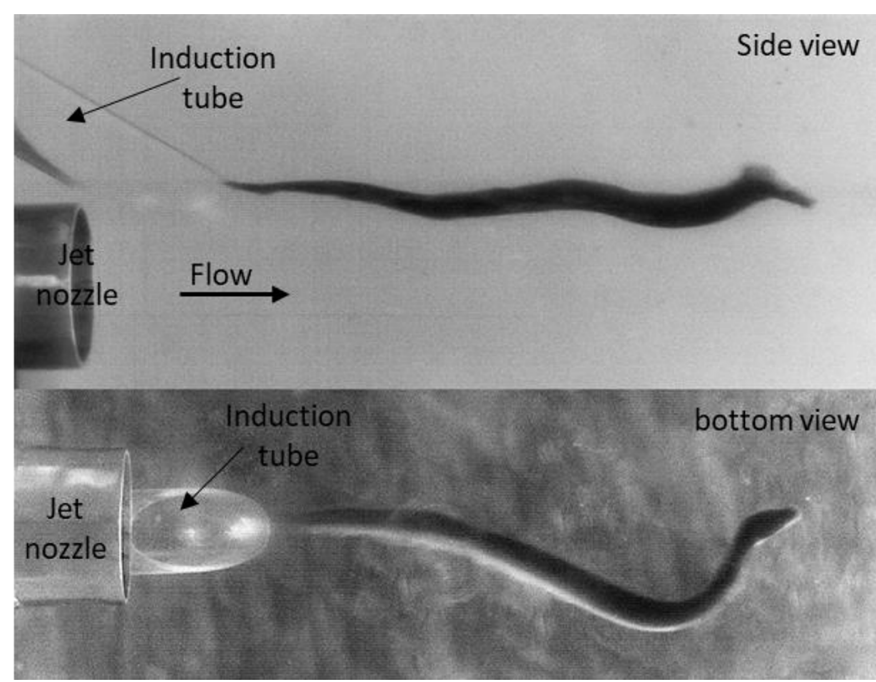

Fig. 2. Frame captures from high speed video (1000 fps) of American eel exposed to a jet of water simulating exposure to fluid shear during turbine passage.

calculated following the methods described by Neitzel et al. (2004), where the shear flume was calibrated by taking detailed measurements of the flow field and strain rate $(e)$ was estimated using the equation:

$$
e=\frac{\Delta \bar{u}}{\Delta y}
$$

where $\bar{u}$ is the mean water velocity $(\mathrm{cm} / \mathrm{s})$ and $y$ is the distance (cm) perpendicular to the force (Neitzel et al., 2004). Neitzel et al. (2004) originally selected a change in distance $(\Delta y)$ of $18 \mathrm{~mm}$, which was based on the width of the fish that were examined. This $\Delta y$ value $(18 \mathrm{~mm})$ has been continually used, independent of the width of the fish that were examined, to determine strain rate for similarly conducted fluid shear studies (Neitzel et al., 2004; Colotelo et al., 2018; Pflugrath et al., 2020). In order to make the results from this study comparable to these previous studies, a value of $18 \mathrm{~mm}$ was used for $\Delta y$ to calculate strain rate. 
Once an eel was exposed, the pump was turned off and the eel was observed by an experienced researcher for any behavioral changes (e.g. erratic swimming), incapacities (e.g. loss of equilibrium), or deformities (e.g. spinal fracture) prior to being dip netted. Once recaptured, eel were placed back into the cartridge, and examined for external injuries including bruising and appendage injury. Eel were then returned to a separate holding trough, where partitions were used to separate fish from each treatment (jet velocity 15,18 , and $0 \mathrm{~m} \mathrm{~s}^{-1}$ ). Fish were held for $48 \mathrm{~h}$ after exposure to observe any delayed mortality and after the $48 \mathrm{~h}$ period eel were euthanized and externally examined a second time for the presence of any injuries.

\section{Results}

When exposed to fluid shear at strain rates of 833 and $1000 \mathrm{~s}^{-1}$, no injuries or behavioral changes were observed in American eel immediately after exposure to fluid shear nor after $48 \mathrm{~h}$ post exposure. When fish were initially placed into the cartridge prior to exposure, a majority of eel immediately began to produce and sluff off mucus. While eel were producing excessmucus, slightly darkened, vertically-oblong spots running along the flank of the fish became evident. These marks dissipated during the post exposure holding period.

\section{Discussion}

American eel were found to have a similar resilience to fluid shear exposure as European eel. Certain morphological traits of freshwater eel are likely to lead to this resilience, including small embedded scales; flexibility due to many small vertebrae; conjoined anal, dorsal and caudal fins; small pectoral fins, and non-protruding eyes and operculum. These traits enable eel to avoid common injuries observed in other species, including descaling, vertebral fractures, and damage to fins, eyes, operculum and gills (Turnpenny et al., 1992; Neitzel et al., 2004; Deng et al., 2005; Colotelo et al., 2018; Pflugrath et al., 2020). A similar resilience to fluid shear was also observed in Pacific lamprey (Entosphenus tridentatus), which share many of these morphological traits (Moursund et al., 2003). Other species which do not possess many of these traits have been examine and were found to be much more susceptible to fluid shear, including American shad and Chinook salmon. Injury rates were greater than $99 \%$ for American shad exposed to shear values that exceeded $500 \mathrm{~s}^{-1}$ and $100 \%$ mortality was observed at a strain rate of $1000 \mathrm{~s}^{-1}$ (Pflugrath et al., 2020). Neitzel et al. (2004) similarly examined several life stages of Chinook salmon and found that the strain rate that affects $10 \%$ of the population ranged from 495 to $607 \mathrm{~s}^{-1}$.

In addition to finding no injuries when exposed to fluid shear up to a strain rate of $1153 \mathrm{~s}^{-1}$, European eel were also observed to have mucus sluff off during the exposures (Turnpenny et al., 1992). This production of excess mucus appears to be a stress reaction to handling and may not necessarily occur due to exposure to fluid shear. However, exposure to fluid shear did appear to remove excess mucus from the eel and may cause the eel to be more susceptible to diseases, as the mucus layer is an eel's first defense against pathogens (Dalmo et al., 1997; Nielsen and Esteve-Gassent, 2006).

The results from this study and previous studies conducted on American eel exposure to rapid decompression and strike indicate that the likely sources of injury and mortality for American eel, and likely other freshwater eels, passing downstream through hydropower turbines is blade strike and/or pinching and grinding (Pflugrath et al., 2019; Saylor et al., 2019). Though American eel are more resilient to strike than other fish species (Saylor et al., 2019), their elongate morphology increases the likelihood of blade strike occurrences during passage through turbines (Ferguson et al., 2008; Deng et al., 2011). Therefore, when designing turbines to promote safe fish passage for eels, designs to reduce the occurrence and severity of blade strike should be considered, such as lower rotational velocity, fewer blades, and thicker blades. Additionally, different edge geometry designs may reduce the occurrence and severity of blade strike.

For this study, fish were exposed to a maximum strain rate of $1000 \mathrm{~s}^{-1}$ which is greater than most fish will likely experience during passage through turbines. For example, sensor fish deployments through a Kaplan turbine at Wanapum Dam recorded severe shear events in only $1 \%$ of deployments (Deng et al., 2014). A severe shear event was designated for any Sensor fish recording acceleration values in excess of $932 \mathrm{~m} \mathrm{~s}^{-2}$. Previous studies have correlated Sensor Fish acceleration to strain rates achieved at various jet velocities within the shear flume (Pflugrath et al., 2020), and an acceleration event of $932 \mathrm{~m} \mathrm{~s}^{-2}$ would likely result in a strain rate exposure of approximately $1000 \mathrm{~s}^{-1}$. However, there is potential that fish may be exposed to strain rates in excess of $1000 \mathrm{~s}^{-1}$, and some turbines, such as Francis type, may be more likely to produce excessive fluid shear (Fu et al., 2016). In these cases, injuries and mortality may be observed due to fluid shear and it may be warranted to study greater strain rates than those examined in this study if fluid shear is expected to commonly exceed $1000 \mathrm{~s}^{-1}$ through a relevant turbine. The shear flume used in this study has a maximum jet exit velocity capacity of $18 \mathrm{~m} \mathrm{~s}^{-1}$ through the $6.35 \mathrm{~cm}$ diameter nozzle, which corresponded to a strain rate of $1000 \mathrm{~s}^{-1}$, therefore modifications would be necessary to exceed this capacity. Additionally, past studies have indicated that flow rates or fish orientation as they enter the turbines may be a factor in injury and mortality rates (Turnpenny et al., 1992; Haro et al., 2000; Amaral et al., 2011). Therefore, if fish are prone to entering an area of fluid shear in an orientation that differs from what was achieved in this study, injury rates may differ and further examination is needed.

\section{Conclusion}

Similar to European eel, yellow-phase American eel have a high resilience to fluid shear (Turnpenny et al., 1992). Additionally, American eel are resilient to rapid decompression (Pflugrath et al., 2019). Therefore, injuries and mortality of American eel passing through hydropower facilities are likely caused by blade strike or pinching and grinding. Measures to improve turbine passage survival for American eel should focus on design and operational aspects that are 
likely to reduce the occurrence and magnitude of these mechanical stressors.

Acknowledgments. This study was funded by the United States Department of Energy, Energy Efficiency and Renewable Energy, Water Power Technologies Office (WPTO). The authors' views expressed in this publication do not necessarily reflect the views of WPTO or the United States government. This research was conducted in compliance with a protocol approved by Pacific Northwest National Laboratory's Institutional Animal Care and Use Committee. The Pacific Northwest National Laboratory is operated for U.S. Department of Energy by Battelle Memorial institute under contract DE-AC05-76RLO 1830.

\section{References}

Amaral SV, Hecker GE, Dixon DA. 2011. Designing leading edges of turbine blades to increase fish survival from blade strike. EPRIDOE, Conference on Environmentally-Enhanced Hydropower Turbines, EPRI Report.

Avise JC, Nelson WS, Arnold J, Koehn RK, Williams GC, Thorsteinsson V. 1990. The evolutionary genetic status of Icelandic eels. Evolution 44: 1254-1262.

Bevelhimer MS, Pracheil BM, Fortner AM, Saylor R, Deck KL. 2019. Mortality and injury assessment for three species of fish exposed to simulated turbine blade strike. Can. J. Fish. Aquat. Sci

Brown RS, Carlson TJ, Gingerich AJ, Stephenson JR, Pflugrath BD, Welch AE, Langeslay MJ, Ahmann ML, Johnson RL, Skalski JR, Seaburg AG, Townsend RL. 2012a. Quantifying mortal injury of juvenile Chinook salmon exposed to simulated hydro-turbine passage. Trans Am Fish Soc 141: 147-157.

Brown RS, Pflugrath BD, Colotelo AH, Brauner CJ, Carlson TJ, Deng ZD, Seaburg AG. 2012b. Pathways of barotrauma in juvenile salmonids exposed to simulated hydrotrubine passage: Boyle's law vs Henry's law. Fish Res 121-122: 43-50.

Čada GF. 1997. Shaken, not stirred: the recipe for a fish-friendly turbine. Waterpower. American Society Civil Engineers

Colotelo A, Mueller R, Harnish R, Martinez J, Phommavong T, Phommachanh K, Thorncraft G, Baumgartner L, Hubbard J, Rhode B. 2018. Injury and mortality of two Mekong River species exposed to turbulent shear forces. Mar Freshw Res 69: 1945-1953.

Dalmo R, Ingebrigtsen K, Bøgwald J. 1997. Non-specific defence mechanisms in fish, with particular reference to the reticuloendothelial system (RES). J Fish Dis 20: 241-273.

Dekker W. 2003. Worldwide decline of eel resources necessitates immediate action: Quabec Declaration of Concern. Fisheries 28: $28-30$.

Deng Z, Carlson TJ, Dauble DD, Ploskey GR. 2011. Fish passage assessment of an advanced hydropower turbine and conventional turbine using blade-strike modeling. Energies 4: 57-67.

Deng Z, Lu J, Myjak MJ, Martinez JJ, Tian C, Morris SJ, Carlson TJ, Zhou D, Hou H. 2014. Design and implementation of a new autonomous sensor fish to support advanced hydropower development. Rev Sci Instrum 85: 115001

Deng ZD, Guensch GR, Mckinstry CA, Mueller RP, Dauble DD, Richmond MC. 2005. Evaluation of fish-injury mechanisms during exposure to turbulent shear flow. Can J Fish Aquat. Sci 62: 1513-1522.

Eyler SM, Welsh SA, Smith DR, Rockey MM. 2016. Downstream passage and impact of turbine shutdowns on survival of silver
American eels at five hydroelectric dams on the Shenandoah River. Trans Am Fish Soc 145: 964-976.

Ferguson JW, Ploskey GR, Leonardsson K, Zabel RW, Lundqvist H. 2008. Combining turbine blade-strike and life cycle models to assess mitigation strategies for fish passing dams. Can J Fish Aquat Sci 65: 1568-1585.

Fu T, Deng ZD, Duncan JP, Zhou D, Carlson TJ, Johnson GE, Hou H. 2016. Assessing hydraulic conditions through Francis turbines using an autonomous sensor device. Renew Energy 99: 1244-1252.

Haro A, Castro-Santos T, Boubée J. 2000. Behavior and passage of silver-phase American eels, Anguilla rostrata (LeSueur), at a small hydroelectric facility. Dana 12: 33-42.

Heisey PG, Mathur D, Phipps JL, Avalos JC, Hoffman CE, Adams SW, De-Oliveira E. 2019. Passage survival of European and American eels at Francis and propeller turbines. J Fish Biol 95: 1172-1183.

Jacobsen M, Pujolar J, Gilbert M, Moreno-Mayar J, Bernatchez L, Als TD, Lobon-Cervia J, Hansen MM. 2014a. Speciation and demographic history of Atlantic eels (Anguilla anguilla and A. rostrata) revealed by mitogenome sequencing. Heredity 113: 432-442.

Jacobsen MW, Pujolar JM, Bernatchez L, Munch K, Jian J, Niu Y, Hansen MM. 2014b. Genomic footprints of speciation in Atlantic eels (Anguilla anguilla and A. rostrata). Mol Ecol 23: 4785-4798.

Jacoby D, Casselman J, Delucia M, Gollock M. 2017. Anguilla rostrata (amended version of 2014 assessment). (accessed March 17, 2020)

Macgregor R, Mathers A, Thompson P, Casselman JM, Dettmers JM, Lapan S, Pratt TC, Allen B. 2008. Declines of American eel in North America: complexities associated with bi-national management, In International Governance of Fisheries Ecosystems: Learning from the Past, Finding Solutions for the Future, American Fisheries Society, Bethesda, Maryland, pp. 357-381.

Moursund RA, Dauble DD, Langeslay M. 2003. Turbine intake diversion screens: investigating effects on Pacific lamprey. Pacific Northwest National Lab.(PNNL), Richland, WA (United States)

Neitzel DA, Dauble DD, Čada GF, Richmond MC, Guensch GR, Mueller RP, Abernethy CS, Amidan BG. 2004. Survival estimates for juvenile fish subjected to a laboratory-generated shear environment. Trans Am Fish Soc 133: 447-454.

Neitzel DA, Richmond MC, Dauble DD, Mueller RP, Moursund RA, Abernethy CS, Guensch GR. 2000. Laboratory studies on the effects of shear on fish. Pacific Northwest National Lab. (PNNL), Richland, WA (United States)

Nielsen ME, Esteve-Gassent M. 2006. The eel immune system: present knowledge and the need for research. J Fish Dis 29: 65-78.

Pflugrath BD, Boys CA, Cathers B. 2018. Predicting hydraulic structure-induced barotrauma in Australian fish species. Mar Freshw Res 69: 1954-1961.

Pflugrath BD, Brown RS, Carlson TJ. 2012. Maximum neutral buoyancy depth of juvenile Chinook salmon: implications for survival during hydroturbine passage. Trans Am Fish Soc 141: $520-525$.

Pflugrath BD, Harnish R, Rhode B, Beirao B, Engbrecht K, Stephenson JR, Colotelo AH. 2019. American eel state of buoyancy and barotrauma susceptibility associated with hydroturbine passage. Knowl Manag Aquat Ecosyst 20

Pflugrath BD, Harnish RA, Rhode B, Engbrecht K, Beirão B, Mueller RP, Mccann EL, Stephenson JR, Colotelo AH. 2020. The susceptibility of juvenile american shad to rapid decompression and fluid shear exposure associated with simulated hydroturbine passage. Water 12: 586 
B.D. Pflugrath et al.: Knowl. Manag. Aquat. Ecosyst. 2021, 422, 20

Pujolar JM, Jacobsen M, Als TD, Frydenberg J, Magnussen E, Jónsson B, Jiang X, Cheng L, Bekkevold D, Maes G. 2014. Assessing patterns of hybridization between North Atlantic eels using diagnostic single-nucleotide polymorphisms. Heredity 112: 627-637.

Saylor R, Fortner A, Bevelhimer M. 2019. Quantifying mortality and injury susceptibility for two morphologically disparate fishes exposed to simulated turbine blade strike. Hydrobiologia 842: $55-75$.

Tremblay V. 2012. COSEWIC assessment and status report on the American eel Anguilla rostrata in Canada, COSEWIC

Turnpenny AW, Davis M, Fleming J, Davies J. 1992. Experimental Studies Relating to the Passage of Fish and Shrimps Through Tidal Power Turbines

Cite this article as: Pflugrath BD, Mueller RP, Engbrecht K, Colotelo AH. 2021. American eel resilience to simulated fluid shear associated with passage through hydroelectric turbines. Knowl. Manag. Aquat. Ecosyst., 422, 20. 